\title{
Enamel hardness differences after topical application of theobromine gel and Casein Phosphopeptide-amorphous Calcium Phosphate
}

\author{
Tamara Yuanita, Nanik Zubaidah and Mifta Izha A R \\ Department of Conservative Dentistry, \\ Faculty of Dental Medicine, Universitas Airlangga \\ Surabaya, Indonesia
}

\begin{abstract}
Background: Most soft drinks contain citric acid / phosphoric acid with pH $<3.5$. Strong acids in the oral cavity cause tooth erosion. Tooth erosion leads to demineralization enamel. Remineralization can prevent demineralization process. One of the commercial remineralization agents is Casein Phosphopeptide-amorphous Calcium Phosphate (CPP-ACP) but it has low solubility and less affordable price. Therefore, a natural ingredients such as theobromine from cocoa extract need to be developed as remineralization agent. Purpose: To determine enamel hardness differences due to topical application of theobromine gel and CPP-ACP. Methods: incisive crowns were cut off (1x1) cm then planted in cylindrical acrylic resin. All samples were immersed with citric acid for 90 minutes then divided into 3 groups. Group I (control) was immersed with aquades (96 min), group II was applied with theobromin gel $200 \mathrm{mg} / \mathrm{l}$ (96 min), group III was applied with CPP-ACP (96 min). By using vickers hardness tester, enamel hardness be measured (15 sec) at 3 points. Results: There were significant differences between the control group, CPP-ACP group, and theobromine gel group. Conclusion: Enamel hardnesse with theobromine gel application is higher than CPP-ACP application.
\end{abstract}

Keywords: remineralization; demineralization; theobromine; CPP-ACP; enamel hardness

Correspondence: Tamara Yuanita, Department of Conservative Dentistry, Faculty of Dental Medicine, University Airlangga, Jl. Mayjend Prof. Dr. Moestopo No. 47 Surabaya, 60132, Indonesia, Email address: tamara-y@fkg.unair.ac.id

\section{INTRODUCTION}

Citric acid which mostly contained in soft drinks has $\mathrm{pH}$ $<3.5^{(1)}$. Strong acids in the oral cavity can cause tooth erosion. Tooth erosion is irreversible loss of hard tissue caused by non-bacterial chemical processes ${ }^{(2)}$. That loss is demineralized process. Demineralized teeth can be remineralized by commercialized remineralization agents such as, fluoride, xylitol, and casein calsium phosphopeptides $(\mathrm{CPP}-\mathrm{ACP})^{(3)}$. CPP-ACP is a nanocomplex which is known as an ingredient to increase tooth resistance to caries. The mechanism of CPP-ACP is by releasing calcium and phosphate ions from ACP. Under acidic conditions, the ions form can increase enamel remineralization ${ }^{(4)}$. Haghgou et $a l^{(5)}$, stated that hardness of demineralized enamel has increased after CPP-ACP and Three Calcium Phosphate (TCP) application. However, CPP-ACP has a disadvantage such as less affordable for middle-to-lower society. ${ }^{(6)}$

Hence, the remineralization concept using natural ingredients can be an alternative due to relatively safer and cheaper. With advancements in plants, remineralization effects become important to develop, one of which is cocoa beans (Theobroma cacao L.). Previous studies have shown that theobromine solution can increase enamel hardness and prevent caries. ${ }^{(7)}$ Study by Mohammed, ${ }^{(8)}$ showed that the remineraization effects of theobromine gel and Casein Calsium Phosphopeptides-Amorphous Calsium Phosphate with Flouride (CPP-ACPF) are not significantly different.

The demineralization process and the remineralization process of the above materials can be observed through enamel hardness changes. ${ }^{(7)}$ The initial stage of demineralization can be detected through enamel hardness test because its sensitivity to superficial lesions. ${ }^{(9)}$ Therefore, enamel hardness testing can be a parameter of this study. The aims of this study is to explain differences in enamel hardness after topical application of theobromine gel and CPP-ACP.

\section{MATERIALS AND METHODS}

This study is a in vitro laboratory experimental using a post test control group design. There are three principal steps in this methods (1) Making theobromine gel at BPKI Ketintang Surabaya, (2) samples preparation, (3) Enamel 
hardness testing at NDT Laboratory, PT PAL.INDONESIA, Surabaya.

Theobromine gel concentration is $200 \mathrm{mg} / \mathrm{L}(10 \%)$. CPP-ACP is a remineralization agent with a concentration of $10 \%$. The strong acid was used is citric acid 1\% $\mathrm{pH} 2.5$ to simulate the erosion or cariogenic process of soft drinks. Ninety minutes was chosen for citric acid immersion which aims to dissolved the teeth. ${ }^{(10)}$

The sample are incisives bovine. Crown and root of a tooth is cut with carborundum disc then immersed in saline. Crown was cut again by carborundum disc $(1 \mathrm{x} 1 \mathrm{~cm})$. Enamel surface that most flag pitted with sticky tape and putted in glass lab. Mold from the PVC $(2 \times 2 \times 1,5 \mathrm{~cm})$ are put on the glass lab that already sticked with cutting tooth before. PVC is given with Vaseline fist. Resin cold cured put into the PVC mold. After it is set, sticky tape and mold are detached. The result is tooth's labial part that exposed. Then polished with sandpaper (400 and 1500 grit).(11)

All of the sample is measured using Vickers Hardness Tester (VHN-1) (200gr/15s) The sample is immersed in citric acid. Enamel hardness after it demineralization (VNH-2) then rinsed off with aquades. Samples divided into 3 group. First group (control group) samples are immersed by aquades (96 minutes). Second group, the sample was given by 0,5 gram of CPP-ACP (96 minutes). Third group, the sample was given by 0.5 gram theobromine gel (96 minutes). 96 minutes describe optimal fluor using time. Samples rinsed again with aquades. Enamel hardness was measured (VHN-3). The measurements perform at three different points (upper part, middle part and lower part). Then, the three result are averaged. The results were analyzed using the Shapiro-Wilk test, the Levene Test, OneWay ANOVA and the significance test using Tukey HSD.

\section{RESULTS}

This study uses the Matsuzawa Seiki Vickers Hardness tester and the results is enamel hardness value at each indentation, then be calculated the mean and standard deviations for each group. Data obtained was gotten from the measurement of initial enamel hardness, after demineralization with citric acid, and after topical application of various subtances (group I: control, group II: CPP-ACP, Group III theobromine gel).

By using Shapiro-Wilk Test, it shown that all groups have $\mathrm{p}>0.05$ it means the data are normal and homogeneity test with Levene's test shows the value $0,078(\mathrm{p}>0.05)$.
Then continued with One-Way ANOVA, the results obtained $p=0.717(p>0.05)$ which means that there is no significant difference between enamel surface hardness in the initial hardness group.

One-Way ANOVA test is used to determine whether there are any statistically significant differences among the groups after remineralization materials application. Data analysis continued with the Post-Hoc Multiple Comparison Test using the Tukey HSD method to determined that differences exist among the means.

The results of the Post-Hoc Multiple Comparison Test showed that there were significant differences between the enamel hardness of control group with CPP-ACP group, the control group with theobromine gel group, and the CPPACP group with theobromine group.

\section{DISCUSSION}

Based on this results, the enamel hardness value decreased significantly in all of groups $(p=0,000)$ after immersed in citric acid. It was caused by enamel demineralization. Demineralization can occure when saliva $\mathrm{pH}$ less than 5,5. (3) Crystal HA is very reactive to Hydrogen ion, then it form $\mathrm{HPO}_{4}^{2-i o n}$. This ion can't survive in hydroxyapatite normal environtment, so crystal HA will dissolve. Along with it, mineral constituent of crystal HA will loose. Continous process will form porocity which cause enamel hardness decreased. The result is in accord with Dzulfia et al, ${ }^{(12)}$ which immersed the teeth in acid for 90 minutes resulted an enamel hardness decreasing value of $61.3 \%$.

Mean of enamel hardness after remineralization increased in groups II and III. The group III is highest

Table 2. Significances value among the means using Post-Hoc Multiple Comparison Test

\begin{tabular}{|c|c|c|c|}
\hline Group & $\begin{array}{c}\mathrm{I} \\
\text { (control) }\end{array}$ & $\begin{array}{c}\mathrm{II} \\
(\mathrm{CPP}-\mathrm{ACP})\end{array}$ & $\begin{array}{c}\text { III } \\
\text { (Theobromine } \\
\text { gel) }\end{array}$ \\
\hline I (control) & & $\mathrm{p}=0.005^{*}$ & $\mathrm{p}=0.000^{*}$ \\
\hline II (CPP-ACP) & & & $\mathrm{p}=0.000^{*}$ \\
\hline $\begin{array}{l}\text { III } \\
\text { (Theobromine } \\
\text { gel) }\end{array}$ & & & \\
\hline
\end{tabular}

Table 1. Enamel hardness mean and standard deviation in each group

\begin{tabular}{lcccc}
\hline \multirow{2}{*}{ Group } & \multicolumn{3}{c}{ Enamel hardness (VHN) } & \multirow{2}{*}{ Standard deviation } \\
\cline { 2 - 4 } & Initial & $\begin{array}{c}\text { After } \\
\text { Demineralization }\end{array}$ & After Topical application & 4.1 \\
\hline Control $(\mathrm{n}=6)$ & 275.75 & 164.43 & 161.55 & 15.0 \\
CPP-ACP $(\mathrm{n}=6)$ & 273.30 & 166.60 & 192.65 & 16.7 \\
Theobromine gel $(\mathrm{n}=6)$ & 279.30 & 158.95 & 223.8 & \\
\hline
\end{tabular}


(theobromine group). This is due to interstitial reaction between theobromine molecule and crystal HA through the enamel microtunnel. Enamel microtunnel has a diameter of $\pm 176 .{ }^{(13)}$ The microtunnel can be passing through by theobromine molecules that smaller in size $(\mathrm{C}=170, \mathrm{H}=$ $152, \mathrm{~N}=152$ ) then inserts into HA crystal structure that already dissolved. ${ }^{(2)}$

Theobromine $\left(\mathrm{C}_{7} \mathrm{H}_{8} \mathrm{~N}_{4} \mathrm{O}_{2}\right)$ molecule binds to crystals HA then replace the crystalline ions. The high-electronegativity of nitrogen and oxygen molecules tend to attract ions $(\mathrm{Ca})$ and phosphates (PO4) with low electronegativity level. Beside that, $\mathrm{H}^{+}$methyl group dissolve easier and replaced by calcium-phosphate. ${ }^{(14)}$ Those two thing are possible for theobromine molecule to attract calcium and phosphate ions, so that the deposition of calcium and phosphate occurs to form a new hydroxyapatite crystal called Theobromine apatite $\left[\mathrm{Ca}_{10}\left(\mathrm{PO}_{4}\right)_{6}\left(\mathrm{OHC}_{7} \mathrm{H}_{8} \mathrm{~N}_{4} \mathrm{O}_{2}\right)\right]$. $^{(15)}$

The second highest enamel hardness is after CPP-ACP application. These hardness value was higher than group I (control). This is might be due to the role of ACP (Amorph Calcium Phosphate) which is bound by CPP (Casein Phosphopeptides) through a cluster of sequnce phosphoryl residues. $^{(16)}$

Amorphous calcium phosphate bonding (ACP) lead to enamel surface and then bind with hydrogen, so that the amorphous bonding break down into calcium and phosphate. These calcium and phosphate ions will bind again with hydrogen to form neutral $\mathrm{CaHPO}_{4} \cdot \mathrm{CaHPO}_{4}$ breaks down into stable calcium and phosphate ions and penetrates into enamel so the supersaturation of calcium and phosphate ions increases. ${ }^{(17)} \mathrm{Calcium}$ and phosphate will bind with $\mathrm{H}_{2} \mathrm{O}$ to form $\left(\mathrm{Ca}_{10}\left(\mathrm{PO}_{4}\right)_{6} \mathrm{OH}_{2}\right)$ or crystal HA. ${ }^{(18)}$ Haghgou et al, ${ }^{(5)}$ states that CPP-ACP is able to increase the microhardness of enamel through ion supersturation.

This study uses aquades as a control group. Aquades are used because aquades are ionized water which does not contain minerals, so it does not cause remineralization effects. ${ }^{(19)}$ It is shown with enamel hardness decreasing in control group even if the sample immerse in aquades for 96 minutes.

The alteration of enamel hardness is higher in theobromine group than CPP-ACP group. This is due to theobromine apatite crystals which is formed by theobromine gel, have a crystal size 4 times larger than hydroxyapatite crystals. ${ }^{(13)}$ The larger crystal size is caused by the dental crystallinity bond through the apatite-forming system. ${ }^{(20)}$ The crystalline molecule formed and the change in crystal hardness cause the crystal density in the enamel to increase so that the tooth structure becomes stronger. ${ }^{(21)}$ Macroscopically it can be observed from the increase in the value of enamel hardness. ${ }^{(22)}$

Whereas, crystal HA which is formed by CPP-ACP are amorphous. Amorphous molecules have different structures with crystalline forms. This amorphous structure does not produce crystal HA with different sizes and shapes. Amorphous form has an irregular structure so that the density of crystals is lower, then they are easier decomposed by external forces. ${ }^{(21)}$ According to Mohammed ${ }^{(8)}$, who showed that the group given theobromine extract have a good remineralization effects than flouride agent (CPPACP w/F). Based on these comparison, it can be shown that the highest enamel hardness is theobromine group followed by the CPP-ACP group, and the lowest was the control group.

\section{CONCLUSION}

Enamel hardness after theobromine gel application is higher than CPP-ACP application.

\section{REFERENCES}

1. Prasetyo EA. Keasaman minuman ringan menurunkan kekerasan permukaan gigi (Acidity of soft drink decrease the surface hardness of tooth). Dent J (Majalah Kedokt Gigi). 2016;38(2):60.

2. Herisa HM, Noerdin A, Eriwati YK. The effect of theobromine $200 \mathrm{mg} / \mathrm{l}$ topical gel exposure duration against surface enamel hardness resistance from $1 \%$ citric acid. J Phys Conf Ser. 2017;884(1).

3. Hemagaran G, Neelakantan P. Remineralization of the Tooth Structure - The Future of Dentistry. Int J PharmTech Res. 2014;6(2):487-93.

4. De Souza CC, Cury JLM, Coutinho TCL, Da Silva EM, Tostes MA. Effect of different application frequencies of CPP-ACP and fluoride dentifrice on Demineralized enamel: A laboratory study. Am J Dent. 2014;27(4):215-9.

5. Haghgou EHR, Haghgoo R, Roholahi MR, Ghorbani Z. Effect of casein phosphopeptide-amorphous calcium phosphate and three calcium phosphate on enamel microhardness. J Contemp Dent Pract. 2017;18(7):583-6.

6. Heyman HO, Swift EJ RA. Sturdevant's Art and Science of Operative Dentistry - South Asian Edition. 2014;(July 2013):25-48.

7. Syafira G, Permatasari R, Wardani N. Theobromine Effect on Enamel Surface Microhardness: In Vitro. J Dent Indones. 2012;19(2):32-6.

8. Mohammed J. Evaluation of remineralization potential of theobromine on human enamel surfaces - An in vitro study Evaluation of Remineralization Potential of Theobromine on Elizabeth Chaly Priyadarshni. Int J Sci Res. 2018;6(11):435-8.

9. Turssi CP, Maeda FA, Messias DCF, Neto FCR, Serra MC, Galafassi D. Effect of potential remineralizing agents on acid softened enamel. Am J Dent. 2011;24(3):165-8.

10. Nasution AI. Jaringan Keras Gigi Aspek Mikrostruktur Dan Aplikasi Riset. 2018.

11. Rina P, Dewi FS, Ellyza H, Zainal AM rsquo ud. Identification of alkaloids of Indonesian Cacao beans (Theobroma cacao L.) and its effect on tooth enamel hardness [Internet]. Vol. 10, Journal of Medicinal Plants Research. 2016. p. 202-8. Available from: http://academicjournals.org/journal/JMPR/ article-abstract/B8613E558108

12. Dzulfia L, Damiyanti M, Herda E. Pengaruh Susu Sapi dan Protein Whey terhadap Kekerasan Email Gigi setelah Demineralisasi The Effect of Bovine Milk and Whey Protein on Enamel Hardness after Demineralization. J Mater Kedokt Gigi. 2016;2(5):28-35. 
13. Nasution AI, Zawil C. The comparison of enamel hardness between fluoride and theobromine application. Int J Contemp Dent Med Rev [Internet]. 2015;4. Available from: http:// www.ijcdmr.com/index.php/ijcdmr/article/view/35

14. Sanphui P, Nangia A. Salts and Co-crystals of Theobromine and their phase transformations in water. $\mathrm{J}$ Chem Sci. 2014;126(5):1249-64.

15. Nakamoto T, Falster AU, Simmons WB. Theobromine: A Safe and Effective Alternative for Fluoride in Dentifrices. J Caffeine Res [Internet]. 2016;6(1):1-9. Available from: http://online.liebertpub.com/doi/10.1089/jcr.2015.0023

16. Al-Batayneh OB. Evidence-Based Recommendations. Smile Dent J. 2009;4(1):1-4.

17. Hasanah I, Setyorini D. Kadar Ion Fosfat dalam Saliva Buatan Setelah Aplikasi CPP-ACP ( Casein PhosphopeptidesAmorphous Calcium Phosphate ) ( Phosphate Ion Level in Artificial Saliva After Aplication of CPP-ACP ( Casein. scientific. 2014;000.

18. Divyapriya G, Yavagal P, Veeresh D. Casein phosphopeptide- amorphous calcium phosphate in dentistry: An update. Int J Oral Heal Sci [Internet]. 2016;6(1):18. Available from: http:// www.ijohsjournal.org/text.asp?2016/6/1/18/186660

19. Nugroho JJ, Hafsari WR. The effectiveness of betel leaf (Piper betle Linn) extract gel and cocoa bean (Theobroma cacao L) extract gel application against the hardness of enamel surface in vitro. J Dentomaxillofacial Sci [Internet]. 2017;2(1):29. Available from: http://jdmfs.org/index.php/ jdmfs/article/view/450

20. Amaechi BT, Porteous N, Ramalingam K, Mensinkai PK, Ccahuana Vasquez RA, Sadeghpour A, et al. Remineralization of artificial enamel lesions by theobromine. Caries Res. 2013;47(5):399-405.

21. Stachurski ZH. On Structure and Properties of Amorphous Materials. 2011. 1564-1598 p.

22. Irawan MIP, Noerdin A, Eriwati YK. The effect of time in the exposure of theobromine gel to enamel and surface hardness after demineralization with $1 \%$ citric acid. J Phys Conf Ser. 2017;884(1). 